\title{
Abbreviations of the Main Political Parties, 1979-96
}

\section{Left}

PC do B Communist Party of Brazil. A Stalinist party. Created in 1958 as a schism of the Brazilian Communist Party.

PT Workers' Party. A heterogeneous leftist party, ranging from some revolutionary groups to social democrats. Created in 1979.

PCB Brazilian Communist Party. Created in 1922. Renamed the Popular Socialist Party (PPS) in 1992.

PSB Brazilian Socialist Party. An independent leftist party created in 1986. Has a lineage going back to the PSB of the 1946-65 period.

PPS Popular Socialist Party. The new name adopted by the former PCB in 1992.

\section{Center Left}

PDT Democratic Labor Party. A populist party with predominantly social democratic tendencies. Created in 1979.

PSDB Party of Brazilian Social Democracy. Created in 1988 by a dissident group of the PMDB. Follows the line of social democracy. 
PMDB Party of the Brazilian Democratic Movement. Its precursor, the MDB (Brazilian Democratic Movement) was created in 1966 as the official party of opposition to the military regime. Renamed the PMDB in 1979. Since its inception, the PMDB has been a heterogeneous party, but its hegemonic group is centrist. Many conservatives have flocked to the party since 1982.

\section{Center Right}

PTB Brazilian Labor Party. In contrast to the PTB of the 1945-65 period, a predominantly center-right party. Created in 1979.

PDC Christian Democratic Party. Created in 1985. More conservative than its counterpart Christian Democratic parties in many countries. Merged with the PDS in 1993 to form the PPR.

PP Progressive Party. Created in 1993 through a merger of the PST and PTR. Merged with the PPR to form the PPB in 1995.

\section{Right}

PL Liberal Party. A conservative party known for its antistatist discourse. Created in 1985.

PRN Party of National Reconstruction. Created in 1989 by Fernando Collor de Mello as a vehicle for running for president. Virtually disappeared after Collor's impeachment in 1992.

PFL Party of the Liberal Front. A conservative party created by dissidents of the PDS. It was officially founded in January 1985 , but for all practical purposes the party was created in 1984 .

PDS Democratic Social Party. Despite its name, a conservative party. The PDS and its predecessor, Arena (1966-79) provided the partisan support for the military regime. Merged with the PDC in 1993 to form the PPR. 
PPR Reformist Progressive Party. Created in 1993 by the merger of the PDS and the PDC. Merged with the PP to form the PPB in 1995.

PPB Brazilian Progressive Party. Created by the merger of the PPR and PP in 1995.

PRONA National Order Reconstruction Party. Far-right party with a populist leader, Enéas Carneiro. 
Rethinking Party Systems in the Third Wave of Democratization

THE CASE OF BRAZIL 
